\title{
Exploring the Factors Affecting Saudi University Students' In-Class Willingness to Communicate in English
}

\author{
Saud Alenezi ${ }^{1}$ \\ ${ }^{1}$ Department of Languages and Translation, Northern Border University, Arar, Saudi Arabia \\ Correspondence: Saud Alenezi, Department of Languages and Translation, Northern Border University, Arar, \\ Saudi Arabia. E-mail: saud.alenezi@nbu.edu.sa
}

Received: May 28, 2020

Accepted: June 30, 2020 Online Published: July 4, 2020

doi:10.5539/ijel.v10n5p75

URL: https://doi.org/10.5539/ijel.v10n5p75

\begin{abstract}
This study explores perceptions of Saudi university students about the factors that affect their in-class willingness to communicate (WTC) in English. The study is conducted using a qualitative research approach. The sample of the study comprises 30 EFL students enrolled in the Preparatory Year programme at the Northern Border University (NBU) in Arar City, kingdom of Saudi Arabia (KSA). The data were collected through in-depth semi-structured interviews and then analyzed using a thematic content analysis. The results revealed that there are 19 factors affecting the students' in-class WTC in English which can be categorized into three main themes that are learner-related factors (e.g., self-perceived communication competence, fear of making mistakes, fear of being laughed at, feeling of shyness, lack of confidence, being afraid of public speaking, previous communication experience), affective factors (e.g., motivation, second language communicative anxiety, evaluation apprehension), and classroom environment factors (e.g., topic interest, topic familiarity, instructional methods, instructional materials, time, classroom apprehension, instructor, class size, classmates). The study concludes with some pedagogical implications for EFL practitioners about L2 learners' in-class participation in the target language and provides some insights for the improving the learning experience of English as a foreign language.
\end{abstract}

Keywords: communicative competence, EFL learners, L2 anxiety, L2 motivation, WTC in English, in-class WTC in English

\section{Introduction}

The ever-growing demand of English around the World, as a global language, has increased the need for good communication skills among the foreign language learners for them to attain communicative competence. In this respect, the language policy planners have set demanding goals for the leaners to accomplish a high level of accuracy and fluency in the target language. Hence, the attainment of these goals has influenced today's learning approaches on the basis of communicative language teaching (CLT), an approach which originated from Hymes' (1972) notion of "communicative competence" (AL-Garni \& Almuhammadi, 2019). Communicative Language Teaching (CLT), has emphasized the importance of English as a second language (ESL) learners using the target language in order to improve learners' communicative competence (Larsen-Freeman \& Anderson, 2013).

However, some studies (e.g., Kalsoom, Soomro, \& Pathan, 2020; Savignon, 2018) suggested that communicative competence does not necessarily guarantee effective communication as other individual or situational factors in the ESL learning context may affect the communication process. Dornyei (2011), emphasized on the essentialness of learners' competence in the target language, he also argues that their willingness to communicate in the target language was equally important. Researchers construe that some factors related to WTC may facilitate or obstruct L2 students determining their readiness to use the target language (Kalsoom, Soomro, \& Pathan, 2020). Empirical evidence in the previous studies showed that the students who are more proficient in the L2 and have high linguistic competence are sometimes less enthusiastic to use their L2 for communication than other, less proficient students, who seem to have willingness to speak in the target language whenever the chance arises (Yue, 2016; Kalyar, Pathan, Channa, Lohar, \& Khan, 2019). The issue of learners' willingness to communicate in a second language has received considerable attention in the last two decades (Yue, 2016; Lee \& Lee, 2019; Lee, 2020).

However, in the context of Saudi Arabia, many EFL students in the Preparatory Year level, had shown 
unwillingness to speak English in the classroom despite the fact that they studied English in school for approximately eight years, followed by an intensive university-level English course (of around 20 hours), prior to beginning their assigned academic studies. A developing students' communication skills is one of the nationwide English language goals in the KSA. As Alhamdi (2014) construed that teaching speaking skills is often challenging and complicated process at all levels of Saudi education system. Therefore, it is important to investigate the factors that deter some students from communicating in the target language as many are hesitant to use the target language, preferring to remain silent during the English language in-class instruction sessions. There are few studies related to EFL learners' willingness to communicate in English in Saudi Arabia. Turjoman (2016), related the Saudi students' willingness to speak English to their educational background as graduate of public schools to private schools. Other general factors militating speaking in English by Saudi EFL students include lack of basic competence in all language skills and lack of confidence and lack to communicate in English (Ali, Shamsan, Guduru, \& Yemmela, 2019), socio-cultural constraints (Ullah, 2017), fear of making mistakes or fear of criticism, mother tongue influence and feeling shy to speak in target language (Bani Younes \& Albalawi, 2016), self-perceived communication competence, pedagogical, curricular, social interaction of students, and frequency of communication (Alrajhi, 2017).

As evidence emerged from the available empirical literature on L2 WTC, researchers (e.g., Oz, Demirezen, \& Pourfeiz, 2015) on L2 WTC, used more of quantitative enquires in a form of trait-like WTC model to examine learners WTC than qualitative enquiries. Although some few previous studies (Khodarahmi \& Nia, 2014; Yue, 2016; Kalyar, Pathan, Channa, Lohar, \& Khan, 2019; Basoz \& Erten, 2019; Lee, Ju Seong, Lee, \& Kilryoung, 2019), have recommended the usage of qualitative approaches to investigate this phenomena and further recommend for more studies to investigate the factors that facilitate in-class WTC among EFL students using in-depth qualitative data. Tousi and Khalaji (2014) suggested that, for educators to increase their students in-class WTC in the target language, they need to identify and understand the variables that affect those students' willingness to speak or decrease the willingness of learners to speak in the target language. Considering the lack of literature on students' perceptions of the factors affecting in-class WTC in the EFL contexts, particularly in Saudi Arabia, and in align with the recent calls in L2 Willingness to Communicate (WTC) research, the present study seeks to explore in-depth the factors affecting Saudi EFL undergraduate students' in-class WTC, using qualitative inquiry. This is an in-depth study, however, a valuable contribution to this topic within the Saudi context.

\section{Literature Review}

\subsection{The Concept of Willingness to Communicate (WTC)}

The concept of willingness to communicate (WTC) was originally derived from Burgoon's (1976) notion of "Unwillingness to Communicate Scale" (UCS) (Kalyar, Pathan, Channa, Lohar, \& Khan, 2019). The early conception of UCS has two sub-factors, related to actual communicative behaviour, which are "approach-avoidance" and "reward". This concept was later refined by McCroskey and Baer in (1985), who reformed the orientation of the scale from negative to positive. These scholars came up with a new construct which they named as "willingness to communicate" (WTC) scale to measure L1 WTC (McCroskey, 1992). The WTC scale may be regarded, in its early inception, as a personality trait based, affected by more transient and contextual variables (Lee, 2018). After then, WTC was later applied in the L2 communication and learning sphere (McCroskey \& Baer, 1985; MacIntyre \& Charos, 1996), where it was presented as "a readiness to enter into a discourse at a particular time with a specific person or persons, using an L2" (MacIntyre, Clement, Dornyer, \& Noels, 1998, p. 547). This is based on the claim that, L2 learners may not necessarily import their excellent L1 communicative skills into learning L2 unless they developed L2 own communicative skills. McCroskey and Baer (1985), suggested that, there is a similar relationship between the WTC of an individual in different contexts, with different recipients, but people are not showing equivalent WTC levels, in all communicative contexts, and with all recipient styles. McCroskey and Richmond's (1990) study involving participants from multi-cultural contexts (the United States, Australia, Sweden, Micronesia, and Puerto Rico) revealed that there are substantial differences with regard to the communication orientation among the participants from these different contexts (McCroskey \& Richmond, 1990). Other researchers, such as Cao and Philp (2006), and Kang (2005), have emphasized the role of situational WTC in the L2 context. Henceforth, in 1998 MacIntyre et al. created a new theoretical model called "L2 Willingness to Communicate (WTC) Heuristic Pyramid Model". 


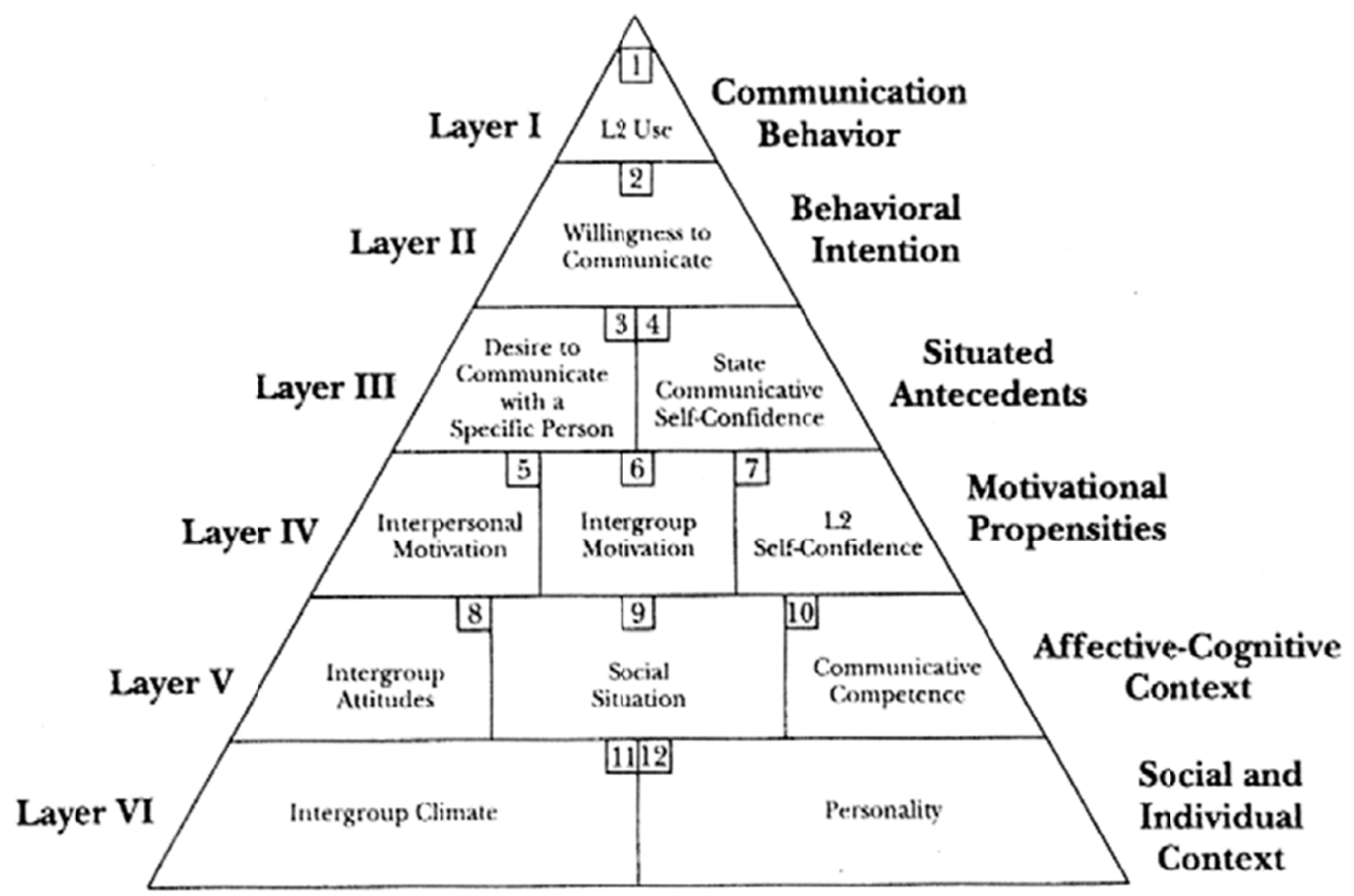

Figure 1. MacIntyre et al.'s (1998) L2 Willingness to Communicate (WTC) Heuristic Pyramid Model

MacIntyre et al.'s (1998) L2 WTC Heuristic Pyramid Model which consists of six categories called "layers" which are divided into two structural areas: intergroup climate and personality. The first three layers are related to "situation-specific influences on an individual's WTC", while the last three layers are related to more lasting effect on an individual's WTC.

\subsection{In-Class Willingness to Communicate (in-class WTC)}

Research conducted in various EFL contexts, underscored the fact that the factors involved in L2 WTC, ranging from learners' personality traits to instructional methods, and classroom environment, consistently guide the learners' degree and manner of response to the demands of their in-class oral participation (Pawlak \& Mystkowska-Wiertelak, 2015; Turjoman, 2016).

More recent studies, in the area of applied linguistics had focused with the notion of in-class with emphasis on how various factors may influence an individual's WTC participation in language classroom activities (Dittmann, 2018; basoz \& Erten, 2019; Lee \& Lee, 2019; Kalyar, Pathan, Channa, Lohar, \& Khan, 2019; Kalsoom, Soomro, \& Pathan, 2020; Lee, 2020). Some of the factors identified in these studies, included the opposite sex, classroom environment, topic, class size, topic pertinence, apprehension, teacher participation, difficulty of the task, time, teamwork and interlocutors, permission to express opinions and an appropriate lexical repertoire, some of which echoed the factors highlighted in the studies cited in the previous paragraph. Allegedly, when students have positive communicative language experience, WTC in the classroom is more likely to be enhanced. This indicated that there are other factors that affect WTC, some of which may be external factors outside the classroom and may require further investigation. The current study, purported to explore such factors affecting Saudi EFL undergraduate in-class WTC.

\subsection{Review of Related Empirical Studies}

Alrajhi (2017), conducted a study to investigate Saudi English majors' WTC in English. He employed a mixed-method design to collect data from 100, level three students. The results of the study, revealed that students with English majors in Saudi Arabia, believed that their English level was moderately competent, and there was a significant positive correlation between the students' communication competence and their willingness to communicate. The results also showed five main factors, affecting the development of students' oral communication competence, including personal, pedagogical, curricular, social interaction of students, and frequency of communication. 
Al-Qurashi (2018), conducted a study to examine the factors that affect oral communication, in English as EFL classrooms. Data were collected from 30 students and 3 lecturers at City University in Saudi Arabia. The findings have related the factors that affect participants' willingness to communicate into two main groups, internal and external. The internal factors listed in this study are motivation, language proficiency, and psychological factors including confidence and shyness. While, the external factors found are related to classroom management, such as: class time and size of the class, teaching approaches, opportunity given to the students, teaching instruments, topic relevancy, use of first language use and code-switching.

A study conducted by Khodarahmi and Nia (2014), found that instructors' class management, and control, had played significant roles to either enhance or constrain learners' propensity to communicate with their peers, or the teachers themselves. This was echoed by a more recent study conducted by Riasati and Rahimi (2018), which found that Iranian EFL learners' enthusiasm to engage in in-class English communication, was influenced by the topic involved, the discourse partner, shyness, self-confidence, the teacher, and the classroom environment.

Yue (2016) investigated Chinese EFL students' in-class willingness to communicate in English. The main aim of this study was to investigate Chinese EFL learners' in-class WTC in actual communication actions. Using qualitative multi-case study research design. The data were collected from five first-year graduate student participants through personal life story interviews, ethnographic classroom observations, followed by stimulus recall interviews, and photo-based interviews. The results confirmed the L2 WTC as a multidimensional and complex concept in nature, and further revealed that the features and paths of learners' L2 WTC are interconnected, dynamic and largely unpredictable.

Kalyar, Pathan, Channa, Lohar, and Khan (2019) investigated Pakintani elementary students' willingness to Communicate (WTC) in ESL classroom. The study employed a quantitative approach adopting a close-ended questionnaire from McCroskey (1992), administered to 300 respondents. The results found that, learners have different purposes for using English in the classroom and that individual differences of learners' willingness to communication (WTC) can be as a result of the integrative motivation and instrumental motivation. Dittmann (2018) related EFL learners' lack of willingness to communicate in English to the low motivation. EFL learners perceived that they do not have enough time to prepare for the class, and in some cases, they rarely give further consideration to issues such as high or low tolerance of ambiguity towards the linguistic and cultural factors and high or low level of anxiety resulting from the class atmosphere.

Basoz and Erten (2019) conducted a study to investigate Turkish EFL students' perceptions pertaining to the factors affecting their in-class WTC in English. A qualitative method was employed in this study. 32 undergraduate EFL students who enrolled in English course at Balikesir University, in Turkey were participated in this study. The participants were recruited purposefully through criterion sampling method. The data were gathered through semi-structured interviews. All the data was analyzed using qualitative content. The results showed that learners' WTC in English classroom was affected by various factors including classroom atmosphere and classmates, instructor and instructional methods and materials, motivation, anxiety and self-perceived communication competence and past communication experience.

In the earlier research, Basoz and Erten (2018) used quantitative methods to study the perception level of Turkish EFL learners 'willingness to communicate in English (WTC) inside and outside the classroom'. 701 EFL students from the departments of Tourism Guidance and Tourism Management at Balıkesir University in Turkey, participated in this study. The results indicated that, in English, EFL learners have a moderate level of WTC. It also found that the perceived rates of their in-class WTC in English and their out-of-class WTC in English were statistically substantially different. Finally, the study showed that students have more willing to communicate in English outside the classroom than inside the classroom.

Lee (2018) conducted a study to track individual changes in Korean students' willingness to communicate in English language. The data were collected using observation and interview from whole class, group, and dyadic interactions across two classroom contexts. The participants were first semester South Korean learners enrolled in ESL course at an American university. The findings revealed that the WTC of the participants fluctuates with regard to the course topic, interlocutors, group size, and the speakers' L2 anxiety level. The study suggested that teachers in L2 classrooms should to take into consideration the various situational factors that can influence or constrain WTC.

In another recent study, Lee (2020) studied EFL students' views on immediacy behaviors, teachers' credibility, and willingness to communicate in-class in a South Korean context. 252 undergraduate Korean learners enrolled in a mandatory English conversation course participated in this study. The participants were divided into two groups, one exposed to native English-speaking instructors and second one exposed to non-native ones. These 
groups were served with questionnaire on teacher immediacy credibility, student willingness to communicate in English, and self-rated English-speaking ability before the end of the semester. The study results showed that the two sub-components of teachers' directness and credibility were positively and significantly related to each other in the two groups. It was also found participants' in-class willingness to communicate were related different sub-components of teacher immediacy and credibility in both groups.

Lee, Ju Seong, Lee and Kilryoung (2019) employed a quantitative approach to investigate the extent to which affective factors (i.e., motivation, self-confidence, risk-taking, L2 speaking anxiety, and grit) and virtual intercultural experiences are associated with willingness to communicate in a second language (L2 WTC) in in-class, out-of-class, and digital settings. 176 Korean EFL undergraduate and graduate students participated in this study. The research results show that demographic and emotional variables and participation in virtual cross-cultural activities have had an important impact on the classroom WTC of EFL students in three different L2 communication environments.

Kalsoom, Soomro, and Pathan (2020), conducted a study to investigate the effects of social support and foreign language anxiety (FLA) on Pakistani EFL students' in-class WTC in English. An adapted WTC questionnaire was given to 200 undergraduates of University of Balochistan, Quetta, Pakistan. The data of the study were analyzed using descriptive and inferential statistics performed using SPSS. The results showed that external factors of social support such as teacher support, parent support and peer group support have significant impact on learners' L2 WTC in English. On the other hand, anxiety has negatively impact on the students' in-class WTC in English with a medium effect size ( $2=.26$ ).

Based on the issues presented and discussed above, the current study will employ a qualitative approach to explore factors responsible for Saudi EFL undergraduate students' in-class WTC. It needs to addresses the following research question:

What are the factors affecting Saudi EFL undergraduate students' in-class willingness to communicate in English?

\section{Methodology}

\subsection{Research Design}

The current qualitative study, explored the factors affecting the Saudi EFL undergraduate students' in-class WTC in English. Qualitative inquiry will help to understand the nature of the phenomenon in question (Creswell, 2012). According to Strauss and Corbin (1998) using qualitative approaches helped researchers to elucidate descriptions of research issues that required in-depth investigation such as emotions or thought. Some of the researchers (such as: basoz \& Erten, 2019; Lee \& Lee, 2019; Kalyar, Pathan, Channa, Lohar, \& Khan, 2019; Kalsoom, Soomro, \& Pathan, 2020; Lee, 2020), recommended that L2 In-class WTC in English need to be investigated through qualitative inquiry to further explore the factors affecting students' willingness to speak English in the L2 classroom.

\subsection{Setting and Participants}

The current study was conducted at the Northern Border University, Arar, Saudi Arabia. 30 students, enrolled in Preparatory Year Studies participated in this study. The participants were recruited through purposive sampling criteria. All the participants are taking general English courses, in their Preparatory Year level. In order to ensure a heterogeneity of samples, the participants recruited including 10 students with the highest CGPA (4.0-5.0), 10 with medium CGPA (3.0-4.9) and 10 with lowest CGPA (0.1-2.9) to take apart in the interviews. This sampling method helped to attain as much variation as possible within the samples (Creswell, 2012). According to Gough and Conner (2006) a sample size of 15 to 30 participants is reasonably accepted in the qualitative study using individual interview.

\subsection{Instrument}

The data were collected using semi-structured interviews. The interview questions were developed by the researcher, and adhered to the requisite concepts presented in the extant of research on WTC in English classroom. However, in semi-structured interviews, researchers were neither able to determine the exact wording of the questions nor the exact order of the questions in advance (Merriam, 1998). Hence, the set of guided questions used in this study included the following.

\subsection{Data Generation Procedure}

All the informants interviewed, were assured of the confidentiality of their responses, and of their anonymity in the research. To ensure confidentiality and anonymity each participant was asked to use a pseudonym not a real 
name. The interviews were audio tapped which lasted for about 30 minutes for each participant. All the interviews were conducted in Arabic since the participants were more comfortable using their mother tongue. The interviewees filled in consent form from which they granted permission to record their voice.

\subsection{Data Analysis}

The interview data were transcribed manually by the researcher using a verbatim transcription. Since the data were initially recorded in Arabic a back to back translation from Arabic to English language was used as recommended by Rubin and Rubin (2011). The transcriptions of these audio-recorded data were repeatedly reviewed by the researcher in order to identify specific speech patterns, and merging themes from the data. The analysis was based on Braun and Clarke's (2006) six steps of thematic analysis, which are as follows: familiarizing with data, generating initial codes, searching for themes, reviewing themes, defining and naming themes, and reporting final results. The data were coded and grouped into themes and sub-themes based on inductive analytical approach. These themes were checked by two lecturers of English with specialization in applied linguistics at the Northern Border University, Arar, Saudi Arabia.

\section{Findings of the Study}

The current study is purported to explore the issue related to the perceptions of Saudi university students' in-class WTC in English. Implying the inductive thematic analysis, the researcher categorized the data into three main themes and 19 sub-themes. into three main themes that are learner-related factors (e.g., self-perceived communication competence, fear of making mistakes, fear of being laughed at, feeling shyness or lack of confidence, being afraid of public speaking, previous communication experience), factors (e.g., motivation, second language communicative anxiety, evaluation apprehension), and classroom environment factors (e.g., topic interest, topic familiarity, instructional methods, instructional materials, time, classroom apprehension, instructor, class size, classmates). Moreover, two codes (WTC) and (UWTC) were used presenting the extracts related to positive responses or willingness to communicate (WTC) and negative response or unwillingness to communicate (unwillingness to communicate).

\subsection{Learner-Related Factors}

The participants have reported some factors that are directly related to learners which can influence their in-class WTC in English. These factors are self-perceived communication competence, fear of making mistakes, fear of being laughed at, feeling shy, lack of confidence, being afraid of public speaking, and students' previous communication experience. Most of these factors have negative effects to the students' in-class WTC in English.

\section{Self-perceived communication competence}

Self-perceived language competence refers to, individual perceptions of students' own ability of communicating in English in this study (Hsu \& Huang, 2017). The participants in this study reported how self-perceived language competence affected their in-class WTC or UWTC in English language. The participants reported self-perceived language competence to have both negative and positive effect to their in-class WRC in English. One of the participants lamented:

I used to decline to talk in English in the classroom, I think my English is not good and my classmates will laugh at me when I speak rubbish. That is why I used to dodge in any circumstance that required to talk in English classes. (UWTC, P2)

Another participant added:

I am outspoken person in my language (Arabic) but in the case is reverse in an English language classroom, generally I am lacking confidence to speak English language. (UWTC, P4)

On the other hand, participant 19 reported a positive influence of self-perceived language competence on in-class WTC in English. He said:

I think my English is fairly good. I used to practice English with my elder brothers and sisters at home so I feel confident to speak in class with my teachers and other classmates. (WTC, P19).

\section{Fear of making mistakes}

Another influential factor, affecting L2 in-class WTC was learners' personal emotion regarding peer of making mistakes in the target language. About half of the participants reported worrying about making mistakes as a cause for their reluctance to speak English in class. This factor has negative effects to L2 students' in-class WTC.

For example, one of the participants reported: 
When I made mistakes in English classroom, I became bored for the rest of that class period. So, most of the time, I feel it is better not to speak in class, because of this fear I don't have willingness to speak English in the classroom. (UWTC, P8)

\section{Fear of being laughed at}

Fear of being laugh at or mocked by other classmates, is another factor explored from the students interviews which have negative effect to the students' in-class WTC in the target language. This factor is closely associated with fear of making mistakes, and students' perceived competence. These are also, related to personality trait that can have negative or positive influence to learners. Some extracts from students' interviews with regard to the fear to talk in the classroom as result of fear of being laugh at or ridicule by classmates are:

As a person, I'm very sensitive to criticism and I get embarrassed easily. Now, some colleagues have great fun with fault-finding, even for reasons that have nothing to do with the ability to speak English. It makes me hesitant to speak English in a class. (UWTC, P20)

Another participant added:

In some cases, I deliberately no participating during English lesson because some of friends make fun of me out of the class. (UWTC, P29)

\section{Feeling shyness}

Feeling shyness is another personality related factor reported by the participants which is affecting them negatively to speak English in a classroom. Moreover, only two participants have reported this factor. One of the participants said:

As a shy person, I become nervous when I speak in public therefore, I feel not secure to speak English in a classroom with teacher or other classmates. (UWTC, P1)

\section{Lack of confidence}

Lack of confidence in particular, is the most factor mentioned by the participants affecting their in-class WTC in English. This is another personality trait factor which can be caused as a result of other learner-related factors mentioned above. For example, students can have confidence to speak in English if they have positive self-perceived competence. One participant reported:

Several students in my group speak English very well. I think this is because they went to international schools. My insufficient background in English makes it difficult for me to speak English the way they do.

That's why I usually prefer to stay silent during the English classes. (UWTC, P11)

Another participant lamented that:

I usually speak in Arabic with my colleagues in class, even when they speak English to me I reply in Arabic

because I don't feel confidence to speak in English. (UWTC, P26)

\section{Being afraid of public speaking}

Being afraid of public speaking, is another factor related to other personality related factors. Twelve participants (out of 30) have reported the fear of public speaking as a constraining factor to their in-class WTC in English. For example, one of the participants reported:

Being an introvert person who doesn't want to speak in public, I always found it difficult to talk in English with teachers or other classmates. (UWTC, P17)

\section{Previous communication experience}

Learners' previous communicative experience can have both negative and positive effects to in-class WTC in English. However, only three participants have reported this factor. One of the participants lamented that:

One day I tried to test my English outside the classroom. I went to a place where I knew there were foreigners. The person at the reception desk could not understand what I was saying. I could not explain why I was there. I still think that it is because of that I don't like to speak English very much now. (UWTC, P22)

On the other hand, another participant mentioned previous communication experience, as a factor that contributed positively to his in-class WTC, in English sharing the following defining moment in this regard:

During my high school I participated in English club, and I like to speak in English with my personal tutor as well. It gives me confidence and to use English in the class. That is why I became outspoken in the class. 
(WTC, P4)

\subsection{Affective Factors}

Three affective factors were elucidated from the students' interviews, to have influence on students' in-class WTC in English. These are, L2 motivation, L2 communicative anxiety and evaluation apprehension. In one way or the other, these factors can be causes of the learners' related factors. These three factors, were discussed explicitly below.

\section{L2 motivation}

L2 motivation can play a significant role in shaping students' learning approaches. The participants admitted that, L2 motivation affected their in-class WTC in English. One of the participants, said:

There is something good about learning English. I was encouraged to be good in by my parents especially my father who is working in Saudi Aramco. He said used to talk with foreigners and non-Arabs in English. This is why I feel motivated to speak in English class because I want to work at Saudi Aramco like my father. (WTC, P5)

Another participant added that:

I try to practice my English by participation in English class. I want to work in Saudi Aramco. I know English proficiency is highly needed by the workers. It also helps to communicate with foreigners and non-Arabs. (WTC, P21)

On the other hand, one participant showed a negative influence of L2 learning motivation as he said:

At present, my highest concern is just to be able to pass the course. Therefore, I am not very eager to speak English in class. (UWTC, P3)

\section{L2 Communicative Anxiety}

Language anxiety is seen as an affective factor influencing the learning of by L2 learners. During expected contact the level of fear and stress is counted as anxiety. Communicative anxiety can be caused as a result of other personality trait related to fears discussed above (such as fear mistakes in speaking, fear of public speaking, and fear of being laughed at). L2 communicative anxiety is negatively affecting the learners' in-class WTC in English. Most of the participants have reported this factor. Some extracts from the students' interviews were reported below.

One participant lamented:

I considered speaking English as difficult because I rarely use it. I have fear that I am not good in spoken English as other students in the class. (UWTC, P13)

Another participant added:

I am worried about speaking English especially in classroom. (UWTC, P5)

On the other hand, one participant reported lack of communicative anxiety as a factor increasing his level of in-class participation in English:

I like speaking English in classroom and I can do that without fear. I started participating to speak in English in class at high school as I said earlier. (WTC, P4)

\section{Evaluation apprehension}

Evaluation apprehension is among the factors affecting students' in-class WTC as reported by the participants. One of them said:

It's like, if I speak, I will make mistakes and the teacher will deduce some marks from me. This is why I prefer writing exam than spoken exam. (UWTC, P19)

\subsection{L2 Classroom Learning Environment Factors}

Some of the factors elucidated from the interview data were related to L2 classroom learning environment. These factors included topic interest, topic familiarity, instructional methods, instructional materials, time, classroom apprehension, instructor, class size and classmates. Participants believed that these factors can play significant roles on the students' in-class WTC in English.

\section{Topic interest}

It has been shown that interest in the topic of conversation is an important factor influencing Saudi EFL 
undergraduate students' in-class WTC in English. Some of the participants perceived that topic interest can have either positive or negative influence on their in-class WTC in English. One participant lamented:

My readiness to speak English increases or decreases according to the topic of discussion. If the topic is interesting, I find it easy to speak. I do not like to speak when the topic is not interesting. For example, telling a story is more interesting than discussing the weather, or computer science. (UWTC, P14)

\section{Topic familiarity}

This factor is closely related to the previous factor discussed above (topic interest). Some topics can be interesting but not familiar by the participants may be as a result of contexts. Some of the participants have mentioned this as an influential factor affecting their in-class WTC in English.

I feel more comfortable to talk about topics I am familiar with such as Saudi culture or history. (WTC, P17) Instructional methods

Few among the participants have related their WTC in English classroom to the instructional methods.

One of the participants said:

I feel more comfortable to participant in English conversation especially depend ending the methods applied by the teachers. I like teachers who allows us to speak and then he gives general comments instead of individual. (WTC, P3)

\section{Instructional materials}

Some of the participants have associated their WTC in the English classroom to the instructional materials in particular. One participant reported:

Usually, I am interested in speaking English, but that depends also on the teaching resources that are presented in the class. I think the materials used by the teachers during this Preparatory Year programme were very good and inclusive. (WTC, P7)

\section{Classroom apprehension}

Classroom anxiety refers to apprehension associated with the classroom environment, which can completely prevent students from succeeding in the classroom. It is clear that learners with classroom apprehension feel insecure, nervous and dreadful in the classroom. Their fear could be so overwhelming to extent that they can barely functional during the classroom session (Wrench, Peck Richmond, \& Gorham, 2009). Students with a high degree of classroom apprehension tend not to communicate with their teacher or their classmates in the English conversation in class with phrases such as "I don't know" in order to avoid participation in English conversation. Most of the participants have reported this factor.

One participant said:

I am afraid of speaking in English classes, most of time I give short answer such as yes or I don't know. (UWTC, P16)

\section{Instructor}

The participants have related their WTC in English in the classroom to their instructors. Some of the instructors were native while others were Arabic speaking. One of the participants reported that his teacher who was a native speaker encouraged them to speak in English class.

As I always try to speak English in the class, one of the instructors who was native always encouraged me to speak. I feel happy when I spoke to him. (WTC, P4)

On the other hand, another student reported negative effect of instructor. As he lamented:

I feel anxious to speak in English in the class especially when the instructor cannot speak Arabic, so that I can explain to him more in Arabic. (UWTC, P28)

Another participant added that:

Most of the time, our instructor is either looking at his lecture notes, the chalkboard or only the students sitting in the front rows. This leaves room for side talks and comments, creating a noisy environment filled with distraction and lack of interest. Like most of the rest of the class, I cannot say I am eager to speak English in such a setting. (UWTC, P6) 


\section{Time}

Few among the participants of the study, have associated their WTC in the English classroom to the time factor. One of them said:

I participate and engage in active conversation in English if the period is not the last period. (WTC, P9)

\section{Class size}

Another factor related to classroom environment is the class size. Here it refers to the number of the students per class.

I feel it is more relaxed and easier for me to speak English in a small class. And it is good that our classes are not overcrowded with 30 to 34 students in a class. (WTC, P22)

Another participant added that:

Our English class is rather large. Sometimes communicative activities can get so disorderly that they seem not to be serious enough. Thus, I feel that it is pointless to participate. My English is good and I am usually interested in conversations where English is used (WTC, P5).

\section{Classmates}

The participants have reported that their classmates play significant roles in influencing them to speak in English class. Moreover, both positive and negative influencing effects were elucidated from the participants' interviews. For examples, some of the participants lamented that their classmates behaved in ways that made them uncomfortable about expressing themselves freely during class. Some of their statements in this regard included the following:

Personally, I would like to use English, at least during lessons, but I find it difficult to act differently from the rest of the group (WTC, P30).

Another participant added:

It makes me uncomfortable when I see some members of the class laugh at other colleague. Their problem is that they don't want to talk just like me but on the other hand laugh when someone made a mistake. (UWTC, P7)

On the other, one participant reported that other classmates increase his willingness to take part in a classroom conversation. As he said:

I get courage to speak in English when I saw other classmates speaking. (WTC, P14)

\section{Discussion}

The current study, investigated Saudi EFL undergraduate students' perceptions, pertaining to factors affecting their in-class WTC in English. The results indicated that several factors influenced their participation in English classroom. The findings have shown, the factors elucidated from the students' interviews that believed to be affecting their WTC in the English classroom. Another important finding of the study was that, there are 19 factors affecting the students' in-class WTC in English which can be categorized into three main themes that are learner-related factors (e.g., self-perceived communication competence, fear of making mistakes, fear of being laughed at, feeling shyness, lack of confidence, being afraid of public speaking, previous communication experience), affective factors (e.g., motivation, second language communicative anxiety, evaluation apprehension), and classroom environment factors (e.g., topic interest, topic familiarity, instructional methods, instructional materials, time, classroom apprehension, instructor, class size, classmates). Moreover, the results showed that Saudi undergraduate EFL students generally had a mixed of both positive and negative perceptions with regards to their in-class WTC in English. Using qualitative enquiry, the findings of this contrasted other studies conducted on L2 WTC using quantitative approaches (e.g., Demirezen \& Pourfeiz, 2015) on L2 WTC used more of quantitative enquires in a form of trait-like WTC model to examine learners WTC than qualitative enquiries. On the other hand, this study is similar with other few studies mainly within the domain of second language WTC in English (Khodarahmi \& Nia, 2014; Yue, 2016; Kalyar, Pathan, Channa, Lohar, \& Khan, 2019; Basoz \& Erten, 2019; Lee, Ju Seong, Lee, \& Kilryoung, 2019) have used qualitative approaches to investigate this phenomena and further recommend for more studies to investigate factors that facilitate in-class WTC among EFL students using in-depth qualitative data.

In particular, English majors held more perceptions toward in-class WTC in English associated with learners-related factors. These factors are related to personality traits, mainly investigated by researchers using quantitative approaches (such as Demirezen \& Pourfeiz, 2015; Kalyar, Pathan, Channa, Lohar, \& Khan, 2019; 
Lee, 2020). The learners' self-concept refers to their overall perspective on cognition, behavior, emotional and psychological abilities, and abilities as students. In addition, the learner's self-concept is the students' views, attitudes, beliefs and values about themselves, and the views of others in the school environment (Wrench, Peck Richmond, \& Gorham, 2009).

Another important finding, have shown that students' lack of competence appeared to be the most negative factor influencing the Saudi EFL students' in-class WTC in English. This confirmed the findings of Hsu and Huang (2017), who found that students who are more positive relationships with other students and their teacher feel more confident when speaking in English. This finding was further supported by MacIntyre's et al. (1998) L2 WTC theory, which postulated that students' level of L2 expertise has a substantial effect on their in-class WTC, in the target language. The results of this study are also consistent with the results of studies such as: Basoz an Erten (2019), Kalyar, Pathan, Channa, Lohar, and Khan (2019), Basoz and Erten (2019), Lee, Ju Seong, Lee and Kilryoung (2019), Yue (2016) Khodarahmi and Nia (2014), which revealed that students' perceived communicative confidence has a significant effect on L2 learners' in-class WTC.

However, there are some differences in terms of the most affecting factors found in each study. For instance, while previous research conducted by Basoz and Erten (2019) found that most factors affecting EFL learners' in-class WTC in English were classmate, followed by instructional methods and L2 motivation, in contrast the present study found that the most factors affecting in-class WTC in English were lack of confidence followed by self-perceived communication competence, and L2 communicative anxiety. Time factor is not found in Basoz and Erten (2019) study. Another important factor related to Saudi in-class WTC in English found in this study was self-perceived language competence.

Moreover, three affective factors, elucidated in the current study (L2 motivation, L2 communicative anxiety \& evaluation apprehension), were also found in some of the studies on L2-WTC, such as Basoz and Erten (2019) (L2 anxiety \& L2 motivation). For instance, the communication anxiety in the classroom setting, may cause a student who is quiet to be viewed in a less favorable way than the outgoing student. Students in the classroom, who more are quiet are considered to be less capable, less knowledgeable, less likely to get into trouble, less likely to do well in school, less likely to be called upon to respond. With regard to the instructor as a factor affecting L2 in-class WTC in English the findings of the present study agreed with Lee's (2020) study, which revealed that sub-components of teacher immediacy and credibility were positively and significantly correlated with each other in both groups. It was also found that, participants' in-class willingness to communicate are related different sub-components of teacher immediacy and credibility in both groups.

On the other hand, Lee's (2018) findings revealed that the WTC of the participants fluctuates with regard to the course topic, interlocutors, group size, and the speakers' L2 anxiety level. This study is also consisted with Riasati and Rahimi's (2018) findings which indicated that Iranian EFL learners' enthusiasm to engage in in-class English communication was influenced by the topic involved, the discourse partner, shyness, self-confidence, the teacher, and the classroom environment. Finally, the current study has expanded the previous research on L2 in-class WTC in English as presented and discussed above. Elucidating various factors responsible of affecting L2 in-class WTC in English ranging from factors related to learners' themselves, affective factors and factors related to L2 classroom setting.

\section{Conclusion and Implications of the Study}

This study, offered new evidence of the English language learning environment within the kingdom of Saudi Arabia. It elucidated various factors related Saudi EFL students' in-class WTC in English. It contributed in understanding the Saudi Preparatory Year students' communicational orientations, which will help in enhancing the students' English-speaking skills. In addition, the study suggested that, class participation by EFL learners can result in better grades and learning outcomes in the target language. It also suggested that instructors can play significant roles in helping students on how to improve communicative confidence and avoid speaking anxiety in the classroom. Another important finding highlighted is that, a few outspoken students tend to dominate the class discussion, so EFL instructors should try to make every student in the class have equal chances to speak. The school setting requires effective communication on the part of both instructors and students. Based on the overall findings obtained, some instructional strategies were suggested for developing positive in-class communicative skills, which include, minimizing anxiety in the classroom, increasing L2 motivation and encouraging learner-self-concept, and avoidance of apprehension. Compared to these recommendations, the findings of the current study offer practical implications targeting Saudi Preparatory Year students. The findings, have implications for EFL classroom participation in the target language and provide insights into the policies and planning for using English in the EFL environment. 


\section{References}

AL-Garni, S. A., \& Almuhammadi, A. H. (2019). The effect of using communicative language teaching activities on EFL students' speaking skills at the University of Jeddah. English Language Teaching, 12(6), 72-86. https://doi.org/10.5539/elt.v12n6p72

Alhmadi, N. S. (2014). English speaking learning barriers in Saudi Arabia: A case study of Tibah University. Arab World English Journal, 5(2), 38-53.

Ali, J. K. M., Shamsan, M. A., Guduru, R., \& Yemmela, N. (2019) Attitudes of Saudi EFL learners towards speaking skills. Arab World English Journal, 10(2), 253-364. https://doi.org/10.24093/awej/vol10no2.27

AlQurashi, H. (2018). Investigating oral communication in EFL classrooms: a case study of a Higher Education Institution in the Kingdom of Saudi Arabia. PhD thesis, University of Reading.

Alrajhi, A. S. (2017). Investigating Saudi English majors' perceived communication competence: Underlying factors and impact on willingness to communicate. $\mathrm{PhD}$ thesis, University of Memphis.

Bani Younes, Z., \& Albalawi, F. (2016). Investigating the factors leading to speaking difficulties: Both perspectives of EFL Saudi learners and their teachers. Arab World English Journal, 7(2), 268-287. https://doi.org/10.24093/awej/vol7no2.18

Basoz, T., \& Erten, I. H. (2018). Investigating tertiary level EFL learners' willingness to communicate in English. English Language Teaching, 11(3), 78-87. https://doi.org/10.5539/elt.v11n3p78

Basoz, T., \& Erten, I. H. (2019). A Qualitative inquiry into the factors influencing EFL learners' in-class willingness to communicate in English. Novitas-ROYAL (Research on Youth and Language), 13(1), 1-18.

Braun, V., \& Clarke, V. (2006). Using thematic analysis in psychology. Qualitative Research in Psychology, 3(2), 77-101. https://doi.org/10.1191/1478088706qp063oa

Cao, Y., \& Philp, J. (2006). Interactional context and willingness to communicate: A comparison of behavior in whole class, group and dyadic interaction. System, 34(4), 480-493. https://doi.org/10.1016/j.system.2006.05.002

Creswell, J. W. (2012). Educational research: Planning, conducting, and evaluating quantitative and qualitative research. London: Pearson Education, Inc.

Dittmann, A. (2018). Correlation between tolerance of ambiguity, anxiety, and willingness to communicate with risk taking in the second language class (p. 291). Economics, Management and Marketing (MAC-EMM).

Dornyei, Z. (2011). Research Method in Applied Linguistic. New York: Oxford University Press.

Gough, B., \& Conner, M. T. (2006). Barriers to healthy eating amongst men: a qualitative analysis. Social Science \& Medicine, 62(2), 387-395. https://doi.org/10.1016/j.socscimed.2005.05.032

Hymes, D. (1972). On communicative competence. Sociolinguistics, 269-293.

Kalsoom, A., Soomro, N. H., \& Pathan, Z. H. (2020). How social support and foreign language anxiety impact willingness to communicate in English in an EFL classroom. International Journal of English Linguistics, 10(2), 78-85. https://doi.org/10.5539/ijel.v10n2p80

Kalyar, J. M., Pathan, H., Channa, M. A., Lohar, S. A., \& Khan, J. (2019). An investigation of willingness to communication in ESL classroom: a quantitative study of elementary students in Pakistan. International Journal of English Linguistics, 9(1), 357-366. https://doi.org/10.5539/ijel.v9n1p357

Kang, S. J. (2005). Dynamic emergence of situational willingness to communicate in a second language. System, 33(2), 277-292. https://doi.org/10.1016/j.system.2004.10.004

Khodarahmi, E., \& Nia, Z. M. (2014). EFL teachers' classroom discipline strategies and learners' willingness to communicate in English inside the classroom. Procedia-Social and Behavioral Sciences, 98, 976-981. https://doi.org/10.1016/j.sbspro.2014.03.507

Larsen-Freeman, D., \& Anderson, M. (2013). Techniques and principles in language teaching (3rd ed.). Oxford handbooks for language teachers. Oxford university press.

Lee, J. H. (2018). The effects of short-term study abroad on L2 anxiety, international posture, and L2 willingness to communicate. Journal of Multilingual and Multicultural Development, 39(8), 703-714. https://doi.org/10.1080/01434632.2018.1435666

Lee, J. H. (2020). Relationships among students' perceptions of native and non-native EFL teachers' immediacy 
behaviours and credibility and students' willingness to communicate in class. Oxford Review of Education, 46(2), 153-168. https://doi.org/10.1080/03054985.2019.1642187

Lee, J. S., \& Lee, K. (2019). Affective factors, virtual intercultural experiences, and L2 willingness to communicate in in-class, out-of-class, and digital settings. Language Teaching Research. https://doi.org/10.1177/1362168819831408

Long, M. H. (1985). Input and second language acquisition theory. In S. Gass \& C. Madden (Eds.), Input in second language acquisition (pp. 377-393). Rowley, Mass: Newbury House.

MacIntyre, P. D., \& Charos, C. (1996). Personality, attitudes, and affect as predictors of second language communication. Journal of Language and Social Psychology, 15(1), 3-26. https://doi.org/10.1177/0261927X960151001

MacIntyre, P., Clement, R., Dornyer, Z., \& Noels, K. A. (1998). Conceptualizing willingness to communicate in a L2: A situational model of L2 confidence and affiliation. The Modern Language Journal, 82, 245-262. https://doi.org/10.1111/j.1540-4781.1998.tb05543.x

McCroskey, J. C. (1992). Reliability and validity of the willingness to communicate scale. Communication Quarterly, 40(1), 16-25. https://doi.org/10.1080/01463379209369817

McCroskey, J. C., \& Baer, J. E. (November, 1985). Willingness to communicate: The construct and its measurement. Paper presented at the Annual Convention of the Speech Communication Association, Denver, $\mathrm{CO}$.

McCroskey, J. C., \& Richmond, V. P. (1982). Communication apprehension and shyness: Conceptual and operational distinctions. Communication Studies, 33(3), 458-468. https://doi.org/10.1080/10510978209388452

Merriam, S. B. (1998). Qualitative research and case study applications in education. San Francisco, CA: Jossey-Bass Publishers.

Öz, H., Demirezen, M., \& Pourfeiz, J. (2015). Willingness to communicate of EFL learners in Turkish context. Learning and Individual Differences, 37, 269-275. https://doi.org/10.1016/j.lindif.2014.12.009

Pawlak, M., \& Mystkowska-Wiertelak, A. (2015). Investigating the dynamic nature of L2 willingness to communicate. System, 50, 1-9. https://doi.org/10.1016/j.system.2015.02.001

Riasati, M. J., \& Rahimi, F. (2018). Situational and individual factors engendering willingness to speak English in foreign language classrooms. Cogent Education, 5(1), https://doi.org/10.1080/2331186X.2018.1513313

Richards, J. C. (2005). Communicative language teaching today (pp. 22-26). Singapore: SEAMEO Regional Language Centre.

Rubin, H. J., \& Rubin, I. S. (2011). Qualitative interviewing: The art of hearing data. sage.

Savignon, S. J. (2018). Communicative competence. The TESOL Encyclopedia of English Language Teaching, 4, 1-7. https://doi.org/10.1002/9781118784235.eelt0047

Strauss, A., \& Corbin, J. (1998). Basics of qualitative research: Techniques and procedures for developing grounded theory. Thousand Oaks, CA: Sage.

Swain, M. (1985). Communicative competence: Some roles of comprehensible input and comprehensible output in its development. In S. Gass \& C. Madden (Eds.), Input and second language acquisition (pp. 235-253). Rowley, MA: Newbury House.

Tousi, M., \& Khalaji, H. (2014). The Impact of Willingness to Communicate on Iranian EFL Learners Speaking Ability. International Research Journal of Applied and Basic Sciences, 8(11), 1866-1869.

Turjoman, M. O. A. A. (2016). Willingness to Communicate in English among Saudi female university students. International Education Studies, 9(7), 170-177. https://doi.org/10.5539/ies.v9n7p170

Ullah, F. (2017). Socio-Cultural Constraints in Learning English Language at Jazan University, Kingdom of Saudi Arabia. International Journal of Language and Linguistics, 5(2), 29. https://doi.org/10.11648/j.ij1l.20170502.11

Wrench, J. S., Peck Richmond, V., \& Gorham, J. (2009). Communication, affect, \& learning in the classroom.

Yue, Z. (2016). Exploring Chinese university EFL learners' 12 willingness to communicate in action: understanding the interplay of self-concept, WTC and sociocultural context through the lens of complexity 
theory. Ph.D. Thesis, University of Birmingham.

\section{Copyrights}

Copyright for this article is retained by the author, with first publication rights granted to the journal.

This is an open-access article distributed under the terms and conditions of the Creative Commons Attribution license (http://creativecommons.org/licenses/by/4.0/). 